\title{
FINANCIAL SUPERVISION STRUCTURE IN ROMANIA. A COMPARATIVE APPROACH
}

\author{
Vasile Cocriş ${ }^{1}$ \\ Bogdan Căpraru
}

\begin{abstract}
In this paper we assess the financial supervision and regulation structure in Romania. To this purpose, we calculate and interpret the Financial Supervision Unification Index (FSU Index) and the Central Bank as Financial Authority Index (CBFA) at the level of the year 2011 (August), according to Masciandaro's methodology (2004) for all EU27 member countries in order to make comparisons with the Romanian ones. We propose a change in the present Romanian financial supervisory regime from the silos model to a hybrid one, arrangement that supposes a combination of the sectoral model with the objectives-centred model.
\end{abstract}

Keywords: central bank, financial stability, Romanian financial supervision and regulation structure, the FSU Index, the CBFA Index

JEL codes: E58, G18, G28, L51

\section{Introduction}

In the context of present financial turmoil, the importance of banking supervision and regulation in order to maintain the financial stability became a very important issue for central bank and supervision authorities. The international financial crisis started in the USA was felt within the Romanian banking system in October 2008 through turbulence on the domestic monetary market. In the next year, this increased in intensity and the banking activity in Romania was faced with downfall. The main effect was the slow-down of the development pace of non-governmental loan, due to the decrease in both demand and offer. As a result of the aggressive crediting policy developed in the last years and the worsening of the financial situation of many companies and population, throughout the year 2009 the quality of the loans' portfolio began to continuously deteriorate.

In this paper we assess the financial supervision and regulation structure in Romania. The paper is structured as follows: the first part consists of a brief literature review while in the second section we assess the Romanian regulation and supervision architecture. To this purpose, we calculate and interpret the Financial Supervision Unification Index (FSU Index) and the Central Bank as Financial Authority Index (CBFA) at the level of the year 2011 (August), according to Masciandaro's methodology (2004) for all EU27 member countries in order to make comparisons with Romanian ones. In the end, we will present the conclusions of this study and some policy recommendations.

This paper is relevant not only for the research in the area, but for policy makers. It discusses about the financial supervision structure in Romania and proposes a change in the present architecture. Also, using the Masciandaro's methodology, we assess how the financial supervision and regulatory structure had developed in EU27 countries between 2004-2011, underling the implication of European integration process and the international financial crises started in august 2007. We indentify a profile of financial supervision and regulatory structure in Romania

\footnotetext{
1 “Al. I. Cuza University of Iaşi, Faculty of Economics and Business Administration, Romania, e-mail: vcocris@uaic.ro

2 “Al. I. Cuza University of Iaşi, Faculty of Economics and Business Administration, Romania, e-mail: csb@uaic.ro
} 
comparing with EU27 countries taking into account the supervisory concentration degree and the central bank involvement in financial supervision and we explain the main factors which shaped it.

\section{Literature review}

The issues regarding financial supervision architecture are studied in many papers. Llewellyn (2006) considers some of the issues involved in organising the institutional structure of financial supervision: why institutional structure is important in the design of optimal regulatory regimes, and why the issue has arisen at the present time; the range of alternative options within a Regulation Matrix; the advantages and potential hazards of integrated, unified, and Twin Peak agencies; the role of the central bank in alternative institutional structures; corporate governance arrangements of regulatory and supervisory agencies and their contribution to the effectiveness of regulation and supervision. Davis and Green (2008) make an essential guide in global financial regulation.

Certain studies deal with which model is appropriate: the multi-agencies model or the integrated one? Hölmström and Milgrom (1991) consider that, in a multitask assignment in monitoring case, the provision of incentives distorts the agency's effort against the activities whose results are less measurable. Dewatripont, Jewitt and Tirole (1999a, b) also argue that a broad mission for an agency will make the market evaluation of the bureaucrats more difficult and therefore provide them with less incentive to exert effort. Gale and Vives (1993), Boot and Thakor (1993) proposed separation between the conflicting tasks "supervision" and "intervention" in order to mitigate passivity in intervention due to the trade off of career concerns and reputation of the regulator. Kane (1984), Romano (1997, 2001), Kupiec and White (1996) underline that a decentralized structure encourages financial innovation. In Garicano and Lastra (2010) view, recent events show that financial innovation is of limited value relative to the risk engendered and more centralized and hierarchical system is needed. Briault (1999) and Llewellyn (1999) emphasize that a single regulator will be more efficient at monitoring these activities. Shleifer (1985) and Dewatripont and Tirole (1999) agree that competition between regulators may generate more information. Briault (1999), Llewellyn (1999), Abrams and Taylor (2002) find that a single regulator will be more transparent and accountable than multiple regulators. Taylor (1995), Kane (1996), Briault (1999), Llewellyn (1999) worry that a single regulator may have excessive power.

Another issue in choosing the optimal financial supervision structure is the central bank involvement or not. Bini Smaghi (2000) provides some evidence with data about 21 industrial countries in the period 1974-1990 that central banks involved in banking supervision deliver on average a higher rate of inflation, even after controlling for the degree of central bank independence. Di Noia and Di Giorgio (1999) present econometric evidence that the inflation rate is higher and more volatile in countries in which the central bank has the monopoly of supervision. Goodhart and Schoenmaker (1995) note that independent central banks, which are generally better at fighting inflation, are also more likely to not have responsibility for banking supervision. From another point of view, Giddy (1994), Lastra, (1992), Abrams and Taylor (2001) affirm that the prestige and independence of central banks enhances their ability to enforce actions and to recruit and retain the best staff. Gulde and Wolf (2004) sustain only a formal involvement of the central bank in the supervision activity.

Some studies deal with the optimal financial supervision model for EU. Di Giorgio and Di Noia (2001) discuss pros and cons of different models for financial market regulation and supervision and present a proposal for the re-organization of regulatory and supervisory agencies in the Euro Area with 4-peak regulatory architecture objectives oriented - macroeconomic stability, microeconomic stability, investor protection and proper behavior, efficiency and competition. Garicano and Lastra (2010) suggest a set of seven principles that must govern the redesign of the EU financial supervision system. Masciandaro (2010) assesses the present EU financial regulation and supervisory reform. Eijffinger (2001) considers that a European Financial Service Authority 
(EFSA) will be able to increase the overall transparency of the banking supervision, because banking and securities market tend to be integrated.

Masciandaro (2004) is the first who has built two indexes which measure financial supervision concentration and central bank involvement in financial supervision. Based on these indexes, there are some studies which assess financial supervision arrangements. In Masciandaro (2007), it is analyzed how the central bank role can influence the unification process of the overall financial supervision architecture. Masciandaro and Quintyn (2010) also test the path-dependence effect describing and evaluating the evolution and the present state of the architecture of six national supervisory regimes in South Eastern Europe (SEE): Albania, Bulgaria, Greece, Romania, Serbia, and Turkey.

\section{Regulation and supervision architecture in Romania}

In practice various models of financial supervision can be met. Four approaches could be identified for financial market supervision and regulation: "institutional supervision", "supervision by objectives", "functional supervision", "single-regulator supervision" and hybrid supervision. The institutional supervision or sectoral supervision or silos model is performed over each single segment of the financial market and is assigned to a distinct agency for the entire complex of activities. In case of the supervisory model by objectives, also called "twin peaks", all intermediaries and markets are subjected to the control of more than one authority, each single authority being responsible for one objective of regulation. The third regulatory model is the socalled "functional supervision", different functions may be regulated differently and by different agencies irrespective of which institutions are performing those functions. The single-regulator supervisory model is based on just one control authority, separated from the central bank, and with responsibility over all markets and intermediaries, being concerned with all the objectives of regulation (stability, transparency and investor protection, maybe competition). The hybrid regime supposes some supervisors monitoring more than one segment of the market and others only one.

The institutional arrangement for regulation and supervision in Romania is organized by financial sectors (institutional supervision). There are four financial sector authorities, the National Bank of Romania (NBR), the National Securities Commission (CNVM), the Insurance Supervisory Commission (CSA), and the Private Pension System Supervisory Commission (PPSSC). This kind of arrangement is also called the vertical (silos) model, with the central bank supervising and regulating the banks, a security regulator, usually a separate commission overseeing the securities markets and an insurance regulator which may or may not be part of a government ministry.

$N B R$ represents the monetary and supervisory authority. The Statute of NBR (Law 312/2004) granted it as an independent public institution with the following tasks in maintaining financial stability: the authorization, regulation and prudential supervision of credit institutions and the oversight of the smooth operation of payment systems with a view to ensuring financial stability (art. 2 (2) b.). In 2006 NBR was also ascribed the role of monitoring and supervising non-banking financial institutions performing credit activities (Law No. 93 of 8 April 2009).

The National Securities Commission (CNVM), established in 1994, by the Law no. 52/1994, is an autonomous administrative authority responsible for regulating and supervising the securities market, the regulated commodity and financial derivative instruments markets, as well as their specific institutions and operations. The CNVM succeeds the Securities Agency established by a Government Ordinance 18/1993 as a general department of the Ministry of Public Finance.

The Insurance Supervisory Commission (CSA), set up by the Law no. 32/2000, is an autonomous specialized administrative authority responsible for the authorization and supervision of insurance companies, reinsurance companies, insurance and/or reinsurance brokers, as well as other intermediaries acting in the insurance and reinsurance business.

The Supervisory Commission of the Private Pensions System (CSSPP) is founded through the Emergency Ordinance no.50, from June 2005, approved by the Law no. 313/November 2005, as an autonomous administrative authority entrusted with the regulation, coordination, supervision and 
control of the activities of the private pensions system, being responsible for the prudential supervision of pension funds.

Some issues regarding customer protection and competition are dealt with by the National Authority for Consumers' Protection and, respectively by The Competition Council. On 28 January 2010 the official launch of the Union of Banking Mediators took place, so as to mediate conflicts and arguments between the bank and the client, such as: the wrong calculation or the enforcement of abusive interests and commissions; errors in the processing of check and card transactions; the refusal to restructure the loan in case of payment default; the introduction of abusive provisions; the enrollment without previous notice or with a fallacious one in the Loan Office; the modification of the reimbursement scheme of the loan without the client's consent.

Table no. 1.

\section{Romanian financial supervision and regulation architecture}

\begin{tabular}{|c|c|c|c|c|c|c|}
\hline Agency & Establishment & $\begin{array}{c}\text { Legal } \\
\text { framework }\end{array}$ & $\begin{array}{c}\text { Independent } \\
\text { agency }\end{array}$ & Financing & Tasks & $\begin{array}{c}\text { Appointment } \\
\text { of the board } \\
\text { member }\end{array}$ \\
\hline NBR & 1990 (2006) & $\begin{array}{l}\text { Law no. } \\
312 / 2004 \text {, } \\
\text { Statute of } \\
\text { NBR }\end{array}$ & Yes & $\begin{array}{l}\text { Self- } \\
\text { financing }\end{array}$ & $\begin{array}{l}\text { - the authorization, } \\
\text { regulation and } \\
\text { prudential supervision } \\
\text { of credit institutions } \\
\text { and the oversight of the } \\
\text { smooth operation of } \\
\text { payment systems with } \\
\text { a view to ensuring } \\
\text { financial stability; } \\
\text { - monitoring and } \\
\text { supervising non- } \\
\text { banking financial } \\
\text { institutions performing } \\
\text { credit activities }\end{array}$ & $\begin{array}{l}\text { The NBR is } \\
\text { managed by a } \\
\text { Board of } \\
\text { Directors } \\
\text { composed by } \\
\text { nine members } \\
\text { appointed by } \\
\text { the Parliament } \\
\text { to which it is } \\
\text { also } \\
\text { accountable. }\end{array}$ \\
\hline CNVM & 1994 & $\begin{array}{l}\text { Law no. } \\
514 / 2002\end{array}$ & Yes & $\begin{array}{l}\text { Self- } \\
\text { financing }\end{array}$ & $\begin{array}{l}\text { - licensing, } \\
\text { authorizing and issuing } \\
\text { norms and regulations } \\
\text { regarding the } \\
\text { supervision in the } \\
\text { security market; }\end{array}$ & $\begin{array}{l}\text { The CNVM is } \\
\text { composed by } \\
\text { seven members } \\
\text { appointed by } \\
\text { the Parliament } \\
\text { to which it is } \\
\text { also } \\
\text { accountable. }\end{array}$ \\
\hline CSA & 2000 & $\begin{array}{l}\text { Law no. } \\
32 / 2000\end{array}$ & Yes & $\begin{array}{l}\text { Self- } \\
\text { financing }\end{array}$ & $\begin{array}{l}\text { - the authorization, } \\
\text { supervision and } \\
\text { regulation of the } \\
\text { insurance sector; } \\
\text { - the resolution of } \\
\text { complaints filed by } \\
\text { policyholders and } \\
\text { injured parties against } \\
\text { insurance undertakings, } \\
\text { professional training } \\
\text { and public } \\
\text { communication. }\end{array}$ & $\begin{array}{l}\text { CSA is } \\
\text { managed by a } \\
\text { Council } \\
\text { composed by } \\
\text { five members } \\
\text { all appointed } \\
\text { by the } \\
\text { Parliament. }\end{array}$ \\
\hline CSSPP & 2005 & $\begin{array}{l}\text { Law no. } \\
313 / 2005\end{array}$ & Yes & $\begin{array}{l}\text { Self- } \\
\text { financing }\end{array}$ & $\begin{array}{l}\text { - authorizing and } \\
\text { supervising the } \\
\text { activities carried out in } \\
\text { the Pension System. }\end{array}$ & $\begin{array}{l}\text { CSSPP is } \\
\text { governed by a } \\
5 \text { member } \\
\text { Council, named }\end{array}$ \\
\hline
\end{tabular}




\begin{tabular}{|l|l|l|l|l|l|l|}
\hline Agency & Establishment & $\begin{array}{c}\text { Legal } \\
\text { framework }\end{array}$ & $\begin{array}{c}\text { Independent } \\
\text { agency }\end{array}$ & Financing & \multicolumn{1}{|c|}{$\begin{array}{c}\text { Tasks } \\
\text { of the board } \\
\text { member }\end{array}$} \\
\hline & & & & & $\begin{array}{l}\bullet \text { to protect the by thent } \\
\text { interests of those } \\
\text { affiliated to the Pension } \\
\text { System, by assuring an Council } \\
\text { efficient functioning of } \\
\text { inis system. }\end{array}$ & $\begin{array}{l}\text { President and } \\
\text { the Vice - } \\
\text { thesident. }\end{array}$ \\
\hline
\end{tabular}

On 31 July 2007, it was signed a Memorandum of Understanding for cooperation in the field of financial stability and financial crisis management, which established the National Committee for Financial Stability. The signatories were the Ministry of Finance, NBR, the CNVM, the CSA and the CSSPP. This Committee is formed by the Ministry of Public Finance, the Governor of NBR, the President of the CNVM, the President of the CSA and the President of the CSSPP. Its main tasks are: the promotion of systematic and efficient information exchange between the sectoral financial regulators and supervisors and the Ministry of Public Finance and the assessment, prevention and the management of financial crises.

On 16 February 2009, the Agreement was amended by an additional act, establishing five specialized technical sub-committees in the framework of the Committee concerning, respectively, financial stability, financial supervision, financial regulation, payment and settlement systems and financial statistics.

The Romanian supervision agencies have also strong links with other national and international institutions, especially with regulatory and supervisory authorities from European Union Member States and with the European Commission.

The National Bank of Romania participates alongside other Member States to strengthen the framework set by the European Union in managing financial crisis. To this purpose, on August 2007, the Governor of the National Bank of Romania signed the Statement of Adherence to the Memorandum of Understanding on high-level principles of co-operation in crisis management situations (signed by the EU countries in 2003) and to the Memorandum of Understanding on cooperation between payment systems overseers and banking supervisors (signed by the EU countries in 2001).

On 1 June 2008, the Memorandum of Understanding on co-operation between the authorities responsible for financial supervision, central banks, and finance ministries from the European Union in the area of financial crisis management, which was signed in 2005, was replaced by the Memorandum of Understanding between the authorities responsible for financial supervision, central banks, and finance ministries from the European Union members in the field of cross-border financial stability. On behalf of Romania, the Memorandum was signed by the National Bank of Romania, the Ministry of Economy and Finance, the National Securities Commission, the Insurance Supervisory Commission and the Private Pension Scheme Supervisory Commission.

From January 2011, the former Lamfalussy Level 3 Committees of supervisors" at EU level was replaced by the establishment of three European supervisory authorities (ESAs) and a European Systemic Risk Board (ESRB). The European System of Financial Supervisors (ESFS) consists of the national financial supervisors and of three new European Supervisory Authorities for the banking, securities and insurance and occupational pensions sectors that is created through the transformation of the existing committees - European Banking Authority, European Securities and Markets Authority, and European Insurance and Occupational Pensions Authority. The European Systemic Risk Board (ESRB) assesses risks to the stability of the entire financial system and issues 
risk warnings and recommendations when necessary. The ECB provides the analytical, statistical, administrative and logistical support to the ESRB.

The three European supervisory authorities (ESAs) established acts as a hub of EU and national bodies safeguarding public values such as the stability of the financial system, the transparency of markets and financial products and the protection of customers (depositors, investors, insurance policy holders, pension scheme members and beneficiaries). The four Romanian supervision authorities collaborate with these bodies - the National Bank of Romanian with the European Banking Authority, The National Securities Commission with European Securities and Markets Authority and, respectively The Insurance Supervisory Commission and The Supervisory Commission of the Private Pensions System with the European Insurance and Occupational Pensions Authority.

\section{Evaluating the Supervisory Concentration and Central Bank Involvement in financial supervision in Romania and EU27 countries: a Comparative Analysis}

\section{Methodology}

In what follows we will assess the degree of involvement of the central bank in the financial regulation and supervision, as well as the degree of concentration of the power of financial supervision and regulation at the level of Romania comparatively with the EU27 countries ones. To this purpose we calculate and interpret the Financial Supervision Unification Index (FSU Index) and the Central Bank as Financial Authority Index (CBFA) at the level of the year 2011 (August), according to Masciandaro's methodology $(2004,2007)$. The sources of data are central banks and supervisory agencies' web pages, financial stability reports and the European Central Bank's Recent developments in supervisory structures report on October 2010. In order to analyse the dynamics of this indices between 2004-2011, we use the scores calculated in Masciandaro (2007) and Masciandoaro and Quintyn (2010).

\section{FSU Index}

The creation of the FSU Index is based on an analysis of which and how many authorities in the sample are empowered to supervise the three traditional sectors of financial activity: banking, securities markets, insurance. For calculating FSU Index we consider only the number of agencies involved in the supervisory activities. At the same time, we do not consider the nature of the authorities involved in the financial supervision setting. To transform the qualitative information into quantitative indications, we assigned a numerical value to each type of authority. Thus, the FSU Index was built on the following scale: $7=$ Single authority for all three sectors (total number of supervisors $=1$ ); $5=$ Single authority for the banking sector and securities markets (total number of supervisors $=2$ ); 3 = Single authority for the insurance sector and the securities markets, or for the insurance sector and the banking sector (total number of supervisors $=2$ ); $1=$ Specialized authority for each sector (total number of supervisors $=3$ ).

Due to the major importance of banking intermediation and securities markets in relation to the insurances a value equal to 5 is assigned to each authority supervising both the banking sector and the securities market. A higher degree of concentration of the supervision power is considered for the integrated authorities that supervise the banking sector and the securities market than for those supervising the banking sector and the insurances, because a higher degree of integration seems to exist between the supervision of banking sector and the securities market than the supervision of banking sector and the insurances. In the case of the countries where a certain financial sector is supervised by two authorities, we may encounter the following situations: the concentration degree is likely to increase when there are two supervisory authorities in a certain sector, if one has supervision prerogatives over a second sector; the concentration degree drops when there are two authorities in a certain sector and neither of them has prerogatives over a second 
sector. In these situations, we will adjust the index as follows: we add 1 if there is at least one sector in the country having two supervisory authorities and one of these two authorities is also responsible for at least another sector; we subtract 1 if there is at least one sector in the country with two authorities assigned for supervision, but none of them is responsible for another sector; 0 other circumstances.

\section{CBFA index}

In every country the central bank is the authority responsible for monetary policy and for the stability of the payment system. The degree of involvement of the central bank in financial supervision can be explained by the specific nature of that institution with respect to the others. Given the three traditional financial sectors (banking, securities and insurance), the CBFA index is equal to: 1 if the central bank has responsibility in no sector; 2 if the central bank has the main (or sole) responsibility for banking supervision; 3 if the central bank has responsibility in any two sectors; 4 if the central bank has responsibility in all three sectors.

Therefore, each national supervisory regime can be identified with at least two characteristics: the degree of concentration of powers (FSU Index) and the degree of involvement of the central bank in that distribution of powers (CBFA Index).

Both indexes are calculated for the year 2011 for all EU27 countries, underlining the Romanian supervision regime features comparatively with the other EU countries. We also undertake an investigation of the financial supervision arrangements reform for the period of 2008 2011 in EU27, to see how policy makers react to the present financial crises.

The sources of the qualitative information in our analysis were: the central banks and supervision authority statutes, the central banks and supervision web pages, financial stability reports, annual reports.

\section{Results}

The results of our investigation can be found in Fig. no. 2. The initials have the following meaning: $\mathrm{B}=$ authority specialized in the banking sector; $\mathrm{BI}=$ authority specialized in the banking sector and insurance sector; $\mathrm{CB}=$ central bank; $\mathrm{G}=$ government; $\mathrm{I}=$ authority specialized in the insurance sector; $\mathrm{S}=$ authority specialized in the securities markets; $\mathrm{U}=$ single authority for all sectors; BS = authority specialized in the banking sector and securities markets; SI = authority specialized in the insurance sector and securities markets.

Table no. 2 .

Supervisory Authorities in EU27 countries: FSU Index and CBFA Index (year: 2011)

\begin{tabular}{|l|l|l|l|c|c|c|c|c|}
\hline \multicolumn{1}{|c|}{ Country } & $\begin{array}{c}\text { Banking } \\
\text { sector }\end{array}$ & $\begin{array}{c}\text { Securities } \\
\text { sector }\end{array}$ & $\begin{array}{c}\text { Insurance } \\
\text { sector }\end{array}$ & Rating & Weight & $\begin{array}{c}\text { FSU } \\
\text { Index } \\
\mathbf{2 0 1 1}\end{array}$ & $\begin{array}{c}\text { CBFA } \\
\text { Index } \\
\mathbf{2 0 1 1}\end{array}$ & $\begin{array}{c}\text { Model } \\
\mathbf{2 0 1 1}\end{array}$ \\
\hline Austria & $\mathrm{U}, \mathrm{CB}$ & $\mathrm{U}$ & $\mathrm{U}$ & 7 & -1 & 6 & 1 & Unified \\
\hline Belgium & $\mathrm{CB}, \mathrm{SI}$ & $\mathrm{CB}, \mathrm{SI}$ & $\mathrm{CB}, \mathrm{SI}$ & 7 & -1 & 6 & 3 & $\begin{array}{c}\text { Twin } \\
\text { Peaks }\end{array}$ \\
\hline Bulgaria & $\mathrm{CB}$ & $\mathrm{SI}$ & $\mathrm{SI}$ & 3 & 0 & 3 & 2 & Hybrid \\
\hline Cyprus & $\mathrm{CB}$ & $\mathrm{S}$ & $\mathrm{I}$ & 1 & 0 & 1 & 2 & Silos \\
\hline Czech Republic & $\mathrm{CB}$ & $\mathrm{CB}$ & $\mathrm{CB}$ & 7 & 0 & 7 & 4 & Unified \\
\hline Denmark & $\mathrm{U}$ & $\mathrm{U}$ & $\mathrm{U}$ & 7 & 0 & 7 & 1 & Unified \\
\hline Estonia & $\mathrm{U}$ & $\mathrm{U}$ & $\mathrm{U}$ & 7 & 0 & 7 & 1 & Unified \\
\hline Finland & $\mathrm{U}$ & $\mathrm{U}$ & $\mathrm{U}$ & 7 & 0 & 7 & 1 & Unified \\
\hline France & $\mathrm{BI}, \mathrm{CB}$ & $\mathrm{S}$ & $\mathrm{BI}, \mathrm{CB}$ & 3 & -1 & 2 & 3 & Hybrid \\
\hline Germany & $\mathrm{U}, \mathrm{CB}$ & $\mathrm{U}$ & $\mathrm{U}$ & 7 & -1 & 6 & 1 & Unified \\
\hline Greece & $\mathrm{CB}$ & $\mathrm{S}$ & $\mathrm{CB}$ & 3 & 0 & 3 & 3 & Hybrid \\
\hline Hungary & $\mathrm{U}$ & $\mathrm{U}$ & $\mathrm{U}$ & 7 & 0 & 7 & 1 & Unified \\
\hline Ireland & $\mathrm{CB}$ & $\mathrm{CB}$ & $\mathrm{CB}$ & 7 & 0 & 7 & 4 & Unified \\
\hline Italy & $\mathrm{CB}$ & $\mathrm{CB}, \mathrm{S}$ & $\mathrm{I}$ & 1 & 1 & 2 & 3 & Hybrid \\
\hline
\end{tabular}




\begin{tabular}{|l|l|l|l|c|c|c|c|l|}
\hline \multicolumn{1}{|c|}{ Country } & $\begin{array}{c}\text { Banking } \\
\text { sector }\end{array}$ & $\begin{array}{c}\text { Securities } \\
\text { sector }\end{array}$ & $\begin{array}{c}\text { Insurance } \\
\text { sector }\end{array}$ & Rating & Weight & $\begin{array}{c}\text { FSU } \\
\text { Index } \\
\mathbf{2 0 1 1}\end{array}$ & $\begin{array}{c}\text { CBFA } \\
\text { Index } \\
\mathbf{2 0 1 1}\end{array}$ & $\begin{array}{c}\text { Model } \\
\mathbf{2 0 1 1}\end{array}$ \\
\hline Latvia & U & U & U & 7 & 0 & 7 & 1 & Unified \\
\hline Lithuania & CB & S & I & 1 & 0 & 1 & 2 & Silos \\
\hline Luxembourg & BS, CB & BS, CB & I, CB & 5 & 1 & 6 & 4 & Hybrid \\
\hline Malta & U & U & U & 7 & 0 & 7 & 1 & Unified \\
\hline Netherlands & CB, U & CB, U & CB, U & 7 & -1 & 6 & 4 & $\begin{array}{l}\text { Twin } \\
\text { Peaks }\end{array}$ \\
\hline Poland & U & U & U & 7 & 0 & 7 & 1 & Unified \\
\hline Portugal & CB & CB, S & I & 1 & 1 & 2 & 3 & Hybrid \\
\hline Romania & CB & S & I & $\mathbf{1}$ & $\mathbf{0}$ & $\mathbf{1}$ & $\mathbf{2}$ & Silos \\
\hline Slovak Republic & CB & CB & CB & 7 & 0 & 7 & 4 & Unified \\
\hline Slovenia & CB & S & I & 1 & 0 & 1 & 2 & Silos \\
\hline Spain & CB & S & I & 1 & 0 & 1 & 2 & Silos \\
\hline Sweden & U & U & U & 7 & 0 & 7 & 1 & Unified \\
\hline UK & U & U & U & 7 & 0 & 7 & 1 & Unified \\
\hline
\end{tabular}

Source: our calculation using dates from central banks and supervisory agencies web pages and reports

As we can see it could be four possible patterns in the interaction between the FSU Index and the CBFA Index, based on the possible combinations of a high or low level of concentration of powers with a high or low level of central bank involvement (Fig. no. 3.). There are two most frequent polarized models: 11 countries with a high concentration of powers with low central bank involvement (Single Financial Authority Regime) and 10 countries with a low concentration of powers with high central bank involvement (Central Bank Dominated Multiple Supervisors Regime). As a preliminary conclusion, in EU27 the degree of supervision consolidation seems to be inversely correlated with the central bank involvement.

The reason of the trade off between the supervision consolidation and the central bank involvement could be explained by the following: because of a fear that the safety net - central bank function of lender of last resort - might be spread to a wider set of institutions than just banks if the central bank is also involved in supervising insurance and securities trading firms (blurring hazard effect); because of fear of creation of a too much powerful bureaucratic agency (monopolistic bureau effect); because of the fact that implementing a monopolistic central bank regime can also be costly when the policymaker also delegates the conduct of business controls to the central bank, an area in which central banks have traditionally sought not to be involved (conflict of interest effect); because the policymaker may face costs in establishing a single financial authority - and thus reducing the central bank's involvement in supervision - if the central bank's reputation is high (reputation effect).

The mean value of FSU Index of old member countries is 5, while the overall sample shows a mean value equal to 4.85. The standard deviation of FSU Index of old member countries is 2.26, while the overall sample shows a standard deviation equal to 2.53 . Therefore the old member countries show a higher and more homogeneous level of concentration.

The mean value of the CBFA Index of new member countries is 1.92 , while the overall sample shows a mean value of 2.19. The standard deviation of the CBFA Index of new member countries is 1.08, while the overall sample shows a standard deviation of 1.21. Thus, the SEE countries show a lower and more homogeneous level of central bank involvement in supervision. 


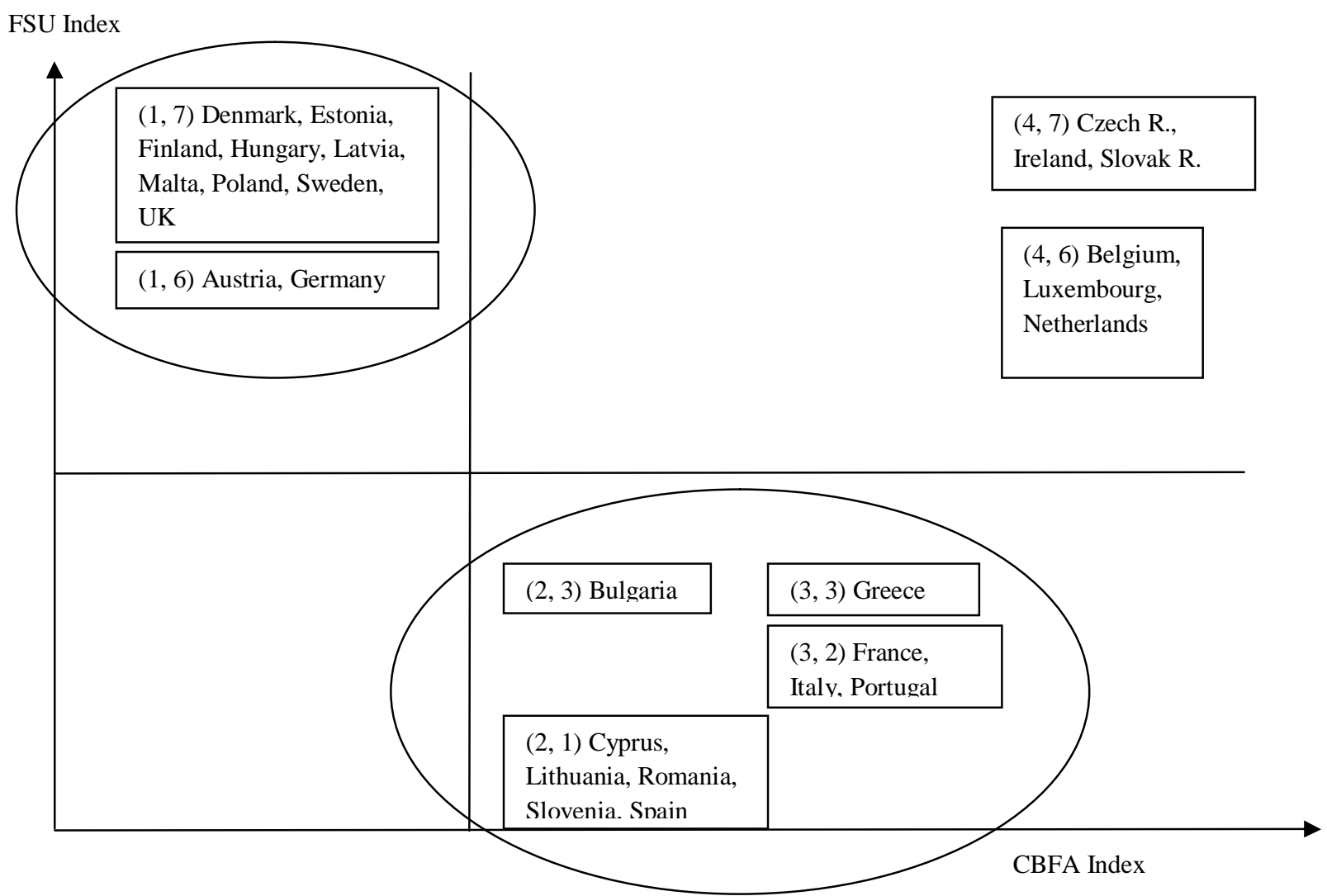

Fig. no. 1. - The trade-off between the CBFA Index and the FSU Index 2011 in EU27

Source: our calculation

The distribution of countries according to the model of supervision is exemplified in the Fig. no. 4. As we can observe, the predominant model in EU27 is the unified (integrated) model. Some countries have reformed their financial supervision architecture, between 2008-2011. Two countries (Germany and Portugal) have changed the vertical (silos) with the hybrid model, one country (Belgium) passed from unified to "twin peaks" and one country (Finland) from hybrid to unified. Thus, we can notice that the silos model tends to be abandoned, and the concentration of power of supervision has increased.

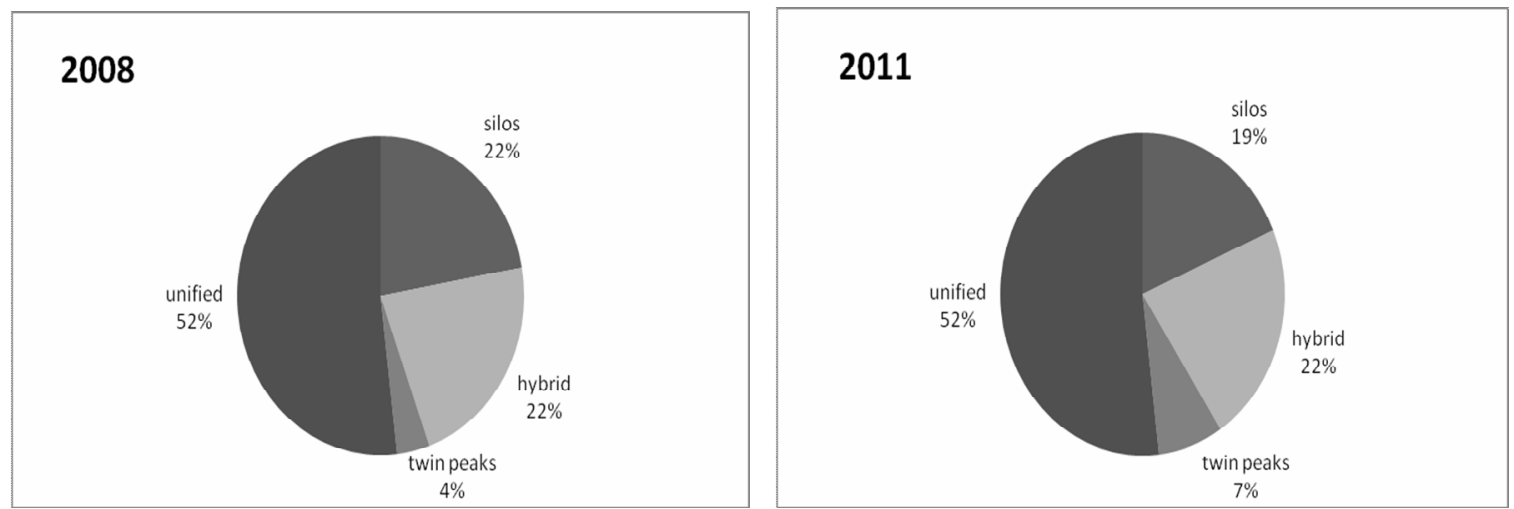

Fig. no. 2. - Models of supervision model in EU27 in 2008 vs. 2011 (\% of total)

Source: our calculation

The model of Romanian financial supervision remained unchanged during the crisis. Romania is numbered between countries with Central Bank Dominated Multiple Supervisors Regime, with the minimum score for FSU Index, beside Cyprus, Lithuania, Slovenia, and Spain. The central bank is involved only in banking sector supervision. The CBFA Index score places 
NBR above new members' average score, but below the old members' one. There are 11 countries with lower CBFA Index than the Romanian one - Austria, Germany, Denmark, Estonia, Finland, Hungary, Latvia, Malta, Poland, Sweden, and UK. Both indexes' scores make Romania the country with the combination of lowest scores beside Cyprus, Slovenia, Lithuania and Spain, being near the low concentration and low central bank involvement pattern.

Even if NBR is involved only in the banking sector, a reality is worth to be mentioned - the Romanian financial system is bank-oriented and the capital, insurance and pension market is less developed and sophisticated. This fact amplifies the role of the Romanian central bank in maintaining the stability of the national financial system.

Another factor that has shaped the present financial supervision regime in Romania is the fact that NBR owns a high reputation gained not only by its oldness, but its succeeded actions in the past, while the transfer of its prerogative in banking supervision to an integrated financial supervision authority could affect its reputation. For years NBR was also the net debtor to the domestic banking system and this could induce a bureaucracy risk, because the Romanian central bank was "captured" by the banking sector and could favor the banking industry by its decisions and disregard the objectives of financial stability. Another bureaucracy risk is the fact that much more power for NBR could cause "abuses of institutional independence", in the context in which it was granted in its statute as an "independent public institution" (Maastricht Treaty condition).

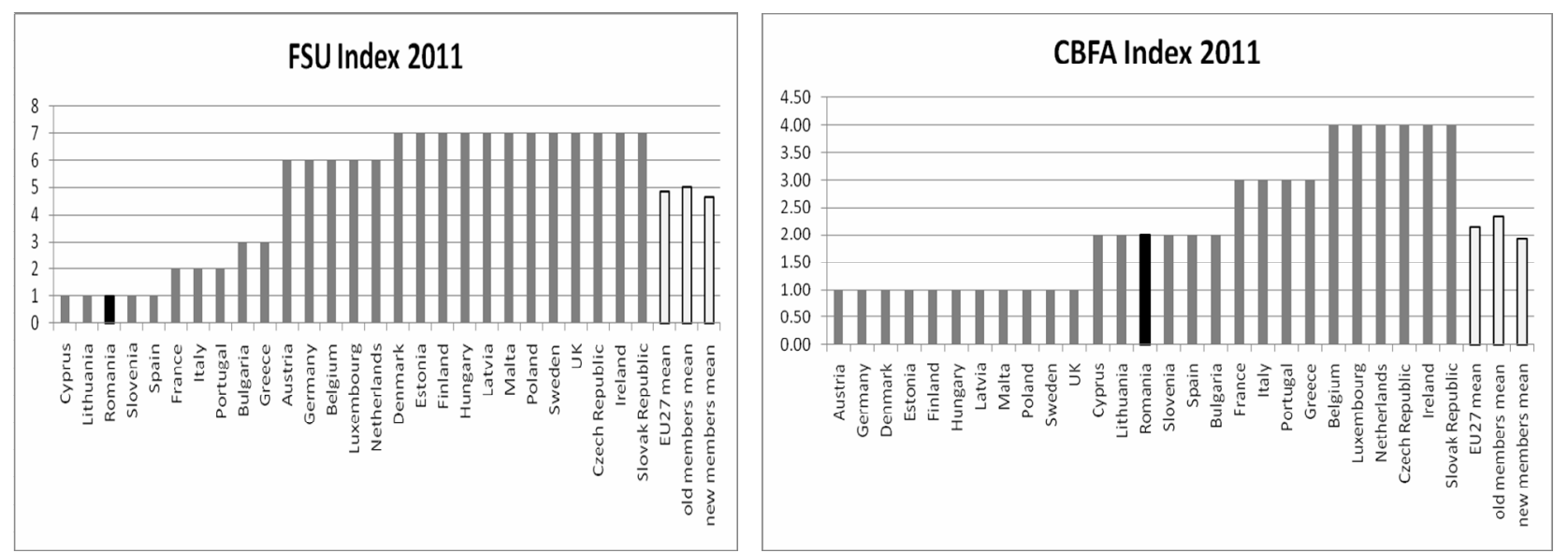

Figure no. 3. - The FSU Index and the CBFA Index scores by countries in EU27 (2011)

Source: our calculation

\section{Conclusions}

In the context of the present international financial crisis the national supervisory architecture in the EU27 countries was reshaped. Some states have chosen to change their model of financial supervision and, for overall, they have increased the concentration of power and the central bank involvement in financial supervision. In this study, using Masciandaro's methodology, we indentify a profile of financial supervision and regulatory structure in Romania comparing with EU27 countries, taking into account the supervisory concentration degree and the central bank involvement in financial supervision and we explain the main factors which shaped it.

The model of the Romanian financial supervision remained unchanged during the crisis and our country is numbered between the countries with Central Bank Dominated Multiple Supervisors Regime. The Romanian FSU Index records the minimum level and the CBFA Index score places NBR above new members' average score, but below the old members' one. Both indexes' scores the FSU Index and CBFA Index - make Romania the country with the lowest scores beside Cyprus, Slovenia, Lithuania and Spain. The main factors of shaping the present financial supervision regime in Romania are: NBR owns a high reputation and the transfer of its prerogative in banking supervision to an integrated financial supervision authority could affect its reputation; for years, NBR was the net debtor to the domestic banking system and this could induce a "bureaucracy risk", 
because the Romanian central bank was "captured" by the banking sector and there might have been the possibility of favoring the banking industry by its decisions and neglecting the objectives of financial stability; much more power for NBR could cause "abuses of institutional independence", in the context in which it was granted in its statute as an "independent public institution". As policy recommendations we propose a change in the present Romanian financial supervisory regime from the silos model to a hybrid one, arrangement that implies a combination of the sectoral model with the objectives-centred model, such as the following: the micro-stability (prudential regulation) of the intermediaries could be maintained at the level of the present four sectoral institutions (NBR, CNVM, CSA, CSSPP), but the transparency in the market, of intermediaries and customer protection and respectively the safeguarding and promotion of competition in the financial intermediation sector should be tackled by two other distinctive integrated agencies (all the activities performed by banking, securities, insurance and pension). This arrangement is arguable because there were many situations of conflicts between customers and financial intermediaries due to abuses caused by the latter, and a specialized authority in financial field is needed when dealing with these issues. The Romanian financial markets are also part of the European single financial market, with no entry barriers for European financial intermediaries. This fact complicates the authorities' mission in safeguarding and promoting the competition in the financial intermediation sector. In the present, the prerogatives of protecting consumers and investors and guaranteeing fair competition are shared by the four sectoral supervisors and certain independent agencies, which act not only in the financial sector (the National Authority for Consumers' Protection, The Competition Council). This is the reason why a financial specialized authority dealing with these issues is needed. This proposal could be extended to the EU level, but this topic will be treated in another research.

\section{Acknowledgement}

This work was supported by the project "Post-Doctoral Studies in Economics: training program for elite researchers - SPODE" co-funded from the European Social Fund through the Development of Human Resources Operational Programme 2007-2013, contract no. POSDRU/89/1.5/S/61755

\section{References}

1. Abrams R. K., Taylor M. W., 2002. Assessing the Case for Unified Sector Supervision, London School of Economics Financial Markets Group Special Papers, 134, London: UK.

2. Bini Smaghi L., 2000. Who Takes Care if Financial Stability in Europe?, forthcoming in Chapter 2 in Open issues in European Central Banking, Mc Millan.

3. Boot A., Thakor A., 1993. Self-Interested Regulation, American Economic Review, 83, 206212.

4. Briault Clive B., 1999. The Rationale for a Single National Financial Services Regulator, Financial Services Authority Occasional Papers, 2, London, UK.

5. Dewatripont M., Tirole J., 1999. Advocates, Journal of Political Economy, 107, 1, 1-39.

6. Dewatripont M., Jewit I., Tirole J., 1999a. The Economics of Career Concerns, Part I: Comparing Information Stuctures, Review of Economic Studies, 66, 183-198.

7. Dewatripont M., Jewit I., Tirole J., 1999b. The Economics of Career Concerns, Part II: Applications to Missions and Accountability of Government Agencies, Review of Economic Studies, 66, 199-217.

8. Davis H., Green D., 2008. Global Financial Regulation. The Essential Guide, Polity Press

9. Di Noia C., Di Giorgio G., 1999. Should Banking Supervision and Monetary Policy Tasks Be Given to Different Agencies?, International Finance, 2:3, 1-18. 
10. Di Noia C., Giorgio G. Di., 2001. Financial Regulation and Supervision in the Euro Area: A Four-Peak Proposal, The Wharton Financial Institution Center, WP 01-02

11. Eijffinger S.C.W., 2001. Should the European Central Bank Be Entrusted with Banking Supervision in Europe? - Tilburg University

12. Gale D., Vives X., 1993. Separation of Authority in Financial Regulation, mimeo.

13. Goodhart Charles A. E., Dirk Schoenmaker. 1995. Should the Functions of Monetary Policy and Banking Supervision be Separated?, Oxford Economic Papers, 47, pp 539-560.

14. Giddy I. H., 1994. Who Should be the Banking Supervisors, paper presented at the seminar on current legal issues affecting central banks, International Monetary Fund, May 10.

15. Gulde A-M., Wolf H.C., 2004. Financial Stability Arrangements in Europe: A Review - OeNB Workshops no. 4, Constitutional Treaty for an Enlarged Europe: Institutional and Economic Implications for Economic and Monetary Union,

16. Garicano L., Lastra R., 2010. Towards a New Architecture for Financial Stability: Seven Principles, CEP Discussion Paper No 990, July

17. Hölmström B., Milgrom P., 1991. Multitask Principal-Agent Analyses: Incentive Contracts, Asset Ownership, and Job Design, Journal of Law, Economics \& Organization, 7, 24-52.

18. Kane E. J., 1984. Regulatory Structure in Futures Markets: Jurisdictional Competition between the SEC, the CFTC and Other Agencies, Journal of Futures Markets, 5, pp 367-384.

19. Kane E. J., 1996. De Jure Interstate Banking: Why Only Now?, Journal of Money, Credit and Banking, 28 (2), pp. 141-161.

20. Kupiec P. H., White P. 1996. Regulatory Competition and the Efficiency of Alternative Derivative Product Margining Systems, Journal of Futures Markets, 16, pp. 943-969.

21. Lastra R., 1992. The Independence of the European System of Central Banks, Harvard International Law Journal, Vol. 33, No. 2, Spring, pp. 475-519.

22. Llewellyn D.T., 1999. The Economic Rationale of Financial Regulation, FSA Occasional Paper No. 1, London, Financial Services Authority.

23. Llewellyn D. T., 2006. Institutional Structure of Financial Regulation and supervision: The basic Issues, World Bank seminar Aligning Supervisory Structures with Country Needs, Washington DC, $6^{\text {th }}$ and $7^{\text {th }}$ June,

24. Masciandaro D., 2004. Unification in financial sector supervision: The trade-off between central bank and single authority, Journal of Financial Regulation and Compliance, Volume 12, Number 2

25. Masciandaro D., 2007. Divide et impera: Financial supervision unification and central bank fragmentation effect European Journal of Political Economy, Elsevier, vol. 23(2), June, 285-315

26. Masciandaro D., 2010. Reforming regulation and supervision in Europe: Five missing lessons from the financial crisis, Intereconomics: Review of European Economic Policy, Springer, vol. 45(5), 293-296

27. Masciandaro D., Quintyn M., 2010. Institutions Matter: Financial Supervision Architecture, Central Bank and Path-Dependence. General Trends and the South Eastern European Countries, South-Eastern Europe Journal of Economics 1, 7-53

28. Romano R., 1997. The Political Dynamics of Derivative Securities Regulation, Yale Journal of Regulation, 14.

29. Romano R., 2001. The Need for Competition in International Securities Regulation, Mimeo, Yale International Centre for Finance, June

30. Shleifer, A.,1985. A Theory of Yardstick Competition, Rand Journal of Economics, 16, 319327.

31. Taylor M., 1995. Twin Peaks: A Regulatory Structure for the New Century, Centre for Financial Innovation, London: UK. 